\title{
Reflections on Movement Patriotic in Elbasan in the Years 1909-1910
}

\author{
Dr. Majlinda Peza - Perriu \\ "Alexander Xhuvani" University \\ History - Gjeography Departament \\ Elbasan, Albania \\ majapeza@yahoo.com
}

Abstract

\begin{abstract}
The development of education in the Albanian territories under Ottoman Empire witnessed a rapid evolution after the announcement of Hyrjetit (the Turkish Constitution of 1908). Thus, in the years 1909-1910 patriotic movement in the Albanian territories will mark a new phase of her, revealed at the opening of schools and courses in Albanian language in the new conditions of constitutional freedoms. In this period, through the organization of the Congress of Monastir displayed in 1908, was unveiled final resolution of the case and the use of a common alphabet writing Albanian language. But despite such a situation, Albanians will not enjoyed for a long period of so-called constitutional freedom. The Young Turks (Young Turks) newly consolidated their political positions in the Ottoman Empire, tried with any form to prevent the spread of great little bit he received learning Albanian. In the years 1909 - 1910, the Albanian National Movement difficulties faced even greater. Through this work we aim to highlight not only the achievements of the patriotic movement in the region of Elbasan Albanian education center, but most are focused on coverage of issues; obstacles and difficulties faced by the patriotic movement in this region in the years 1909-1910. The Young Turks use of all forms and, using all opportunities to curb educational movement in the region of Elbasan, using new tactics more sophisticated you put sticks under the Elbasan Patriots wheels. But it must be said that at the same time, taking advantage of the weaknesses of the Albanian patriotic movement, contradictions and differences that existed between the Albanian political elite of the time. Meanwhile, in moments when new tactics did not give the expected result, they turned to old methods of violence and terror.
\end{abstract}

Keywords: Hyrriet, Young Turks, Congress Monastir, Club poor.

\section{- Introduction}

In the years 1909-1910, the educational movement on Albanian territories had a significant evolution; through the creation of a vast network of clubs and patriotic societies, through the opening of some schools and night courses in Albanian and moreover, culminated with the opening and operation of the first Normal School ${ }^{1}$. Such progress of educational movement in this period, did not happen in a pacific way but was accompanied by several obstacles and difficulties; The first reason was that The Monastery Congress in 1908 did not resolved the issue of the Albanian language alphabet. In the years 1909-1910 the involvement of the Young Turks on the solution of this problem, as a supporter of the Arabic letters on the Albanian lettering, will become a subject on the irritation of the relations between Albanians (who were supporters of the alphabet with Latin letters) and Young Turks, taking the size of an already open conflict. Secondly, it must be admitted that there were divergences of different natures between the Albanian patriots. Moreover, some of them resulting networks members of the Turkish clubs. Meanwhile, the rest of the Albanian political elite forecast the future of Albania with the support of one or another European power if not the Balkans. Thirdly, if in 1908 the Young Turks allowed Albanian's opening the Albanian schools, clubs, patriotic and cultural societies, during 1909, the inability to close them, the Young Turks will change tactics. Thus, to the creation of a network of Albanian clubs, Young Turks will resist by supporting the creation of clubs that represent and protect their interests. Meanwhile, as the French researcher Clyer says: "The Young Turks tried to take control of the Albanianism activities, or tried different ways to weaken it. "2

Such a situation will be present at the same time in the region of Elbasan, where in the years 1908-1909 were created and exercise their educational, patriotic and cultural activities several important clubs and societies in this region, working

\footnotetext{
${ }^{1}$ Normal was the first Albanian school under the Ottoman Empire repressor

${ }^{2}$ Nathalie Clayer, At the beginning of Albanian nationalism, birth of a majority Muslim nation in Europe, Tiranë, "Përpjekja" 2009, f. 556 
closely with patrioticclubsandsocietiesin Albania and abroad. Such were the "Bashkimi" club, "Vllazeria", "Aferdita" society, "the sun", society etc. ${ }^{1}$

\section{- "Club of the poor"}

Referring to domestic resources of that time, in Elbasan in 1909 witnessed the creation of a new club known as "Club of the poor". Interestingly, this club is not figures on the network of patriotic clubs operating in Elbasan in that period. Also, scholars who have written before ' 90 and have treated and reflected concerns of networks of clubs and societies created in Elbasan during that period, do not inform us about the creation of this club and moreover to its functions and activities.

Referring to the approach the relevant documentation, this club turns out to be created on 17 June $1909^{2}$. More complete information for the physiognomy of this club is found in the pages of the "Union of the Nation" newspaper dated October 1, 1909 and published in Bitola under the title "CALL TO ALL ELBASANIAN OUTSIDE ALBANIA". In this publication, "Club of the poor" appear to us as a club with a special physiognomy, resulting as a charitable or human nature club as found in his revealed call, stating: "To be helped all those poor in difficulties without looking on their religion The club will help the sick people, innocent prisoners, the ones who can't pay the king's tax, the ones who can't feed themselves or their family and the mosques and churches that can't afford the expense "3. For this purpose, "Club of the poor" through his call would require financial support to all Albanians at home and abroad. Also, referring to the Statute of the club determined not to accept as members representatives from other social levels, but only who were considered poor, regardless of their financial contribution ${ }^{4}$. Meanwhile, in terms of the character of the "Club of the poor" French researcher Clayer, suggests that this club was specially created by the Young Turks, as a means of pressure on the Albanian clubs and societies that were created in Elbasan at that time. For this problem Nathalie Clayer, wrote: "The Club of the Poor was created by the Young Turks in order to fight Elbasan patriotic clubs and also deal with acts of philanthropy"5.

In this case, we think that the patriotic club referred by researcher turns out to be the club "VIlaznia"6, which according to Clayer, was very active under the direction of Lef Nosi, while the president of the club described as a "less patriotic"7 mister. And as to the purpose of The Club of the Poor, Clayer stated that: "Finally, the Young Turks, to oppose this latest initiative created " The Club of the Poor ", whose shade was too Islamic"8. Thus, time sources confirm the fact that "'" The Club of the Poor ", created two months after the creation of the club "VIlaznia", as an attempt to establish the Young Turks against rival Albanian patriotic clubs, including to poor sections of the population.

Having consulted the relevant archival documents, which reflects the all inclusive activities of patriotic clubs and societies in this period in Elbasan, it turns out that in any case does not appear any moment and relationship or cooperation between them and "The Club of the Poor". Moreover, does not result any information regarding this club directors, whose names, we think, were kept secret. In this context, our opinion regarding The Club of the Poor's physiognomy, resonates with the Clayer researcher's opinion. When we make such a claim, despite the above arguments, we highlight the fact that the club had good relations of cooperation with the Young Turks club "Ihhitad" in Elbasan.

\section{- The conflict over the alphabet issue}

However, it must be said that the rivalries between the Albanian patriots and the Young Turks in the years 1909-1910, in many cases will become open clash between them. In 1910, the Albanian patriots faced a very important and delicate problem, which had to do specifically with the protection of Albanian writing with the Latin alphabet. In this context, the tensions between the Albanians and the Young Turks regarding the problem of the alphabet which already existed, reach their peak. It must be said that in this conflict between Albanians and them, Young Turks also had the support of some Albanian deputies among them those from Elbasan. Expression of these frustrations will be organized rallies to promote

\footnotetext{
${ }_{1}^{1}$ A.Q.SH. Funds (Patriotic clubs and societies) 102, Doss.75.

2 AME, Dossier 14. f. 7. Political and Social opinion of the Albanian Renaissance 1908 - 1910, Zihini Haskaj , II Edition, Tirana 1976, 463 , is known as "The club of the Poor"

3 Political and Social opinion of the Albanian Renaissance 1908 - 1910, Zihini Haskaj , II Edition, Tiranë 1976, 463

4 lbid.

5 Nathalie Clayer, 136

6 "Vllaznia" club (meaning Brotherhood) was created in April 1909 in Elbasan.

7 On the referred source the president of "Vllaznia" club was Dervish Ibrahimi (mr. Biçaku).

8 Nathalie Clayer, 611.
} 
the Young Turks in several cities against the use of the alphabet with Latin letters. In this propaganda, against the use of the Latin alphabet they tried to use especially the Muslim fanatic element, linking the use of the Arabic alphabet on the writing Albanian language on religious issue and considering infidels who would write the letters of the Infidels (Latin). Such a statement was made present at this time in the reports of the Austro-Hungarian consuls in Albania, who said that ". . Their[Young Turks] undeclared goal is sparking religious fanaticism of Muslims to exercise a paralyzing effect on Albanian cultural progress "1.

In this context, since the beginning of 1910, with the support of some Albanian MPs among them, Mahmut Bedri from Peja, Haxhi Ali Elbasani, Fuat Pasha from Pristina, Sait Efendi (Idris) from Skopje, Riza Efendi from Shkodra, Young Turks will require at the Turkish parliament the writting of Albanian with Arabic letters. ${ }^{2}$ Regarding to this problem in the "Sun" newspaper was said: "Haxhi Ali [Elbasan] with 13 other fanatic deputies, officially asked the government to write Albanian with Arabic letters, because otherwise religion would be damaged"3. Thus, after the law passed in parliament, the Young Turks, through the club "Union and Progress" which had branches in many Albanian cities and representatives supporting Muslim clergy, did not delay to implement the use of the alphabet in the Albanian language.

Through the resources of that time is concluded that, in Elbasan supporter Arabic alphabet letters, was noted the Muslim cleric Haxhi Hafiz Sulejman Kungulli. He, enjoying full support of the Elbasan deputy Haxhu Ali, will be described as the organizer of a rally against the latin alphabet - based characters. Such an attitude of Hafez Kungulli is reflected in the "Sun" newspaper in an article titled: "Betrayer Hafës Kungulli and Elbasan fanaticsrally "4. Also, the austro-hungarian consul in Durres about this organized rally would be expressed: "Elbasan one of the pealing of national efforts, wherein the tolerant religious elementis less balanced with fanatical element, will always form the object of the anti Albanian attacks of Young Turks "5. Thus, on February 3, 1910, in Elbasan would be organized a rally supporting of the Arabic alphabet lettering. According to information Austrian Vice Consul in Durres in this rally had not more than 200 people, while in terms of the composition of the participants result that most of them were peasants from Çermenika ${ }^{6}$. In a speech from Hafiz Kungulli in the rally was said that "there should not be left Haxhi Ali, our father alone, what he does, we should hear him. Today is asking us to seal these two letters, (of which one o the was sent to Haki Pasha and the other to Haxhi Ali), these two laws in order to write the Albanian language according to their rules "7. Elbasan deputy Haxhi Ali's attitude will be reflected in an article published in the "Union of the Nation" newspaper stating: ". . Yes, Mr. Haxhi8, the diplomat from Elbasan went further, asked artificial testimony by çermenikas, here in a chapel, got together and put their stamps over some card, which himself had sent in order to be sent as a telegram to the government. "'As found in this document, incentive to oppose the usage of latin letters in writing Albanian language, became especially the appeal of Elbasan Senator and deputy, Haxhi Ali, directed imams of the fanatic muslims.

A month after this event in Elbasan, the Elbasan deputy Haxhi Ali Elbasani will lead society named "Mahfeli" created in Istanbul in March 1910, with the intention of writing Albanian language in Arabic letters ${ }^{10}$. Meanwhile in the newspaper "Sun" his election as deputy regarded as a mistake of Elbasan citizens. ${ }^{11}$

But the organized rally for the protection of the alphabet with Arabic letters couldn't avoid the reaction of the people of Elbasan and its provinces patriots from Gramshi, Shpati, Çermenika etc. It must be said how fast this reaction as "two days

\footnotetext{
$1 \mathrm{lbid}$. Letter sent to the Ministry of Foreign Affairs in Vienna, Durrës, 11 March 1910.

${ }^{2}$ AME, Taken from the Study -Some aspects of the Albanian alphabet issue war in Istanbul,of Hasan Kaleshi, "Shqiptari" Newspaper, Thursday 18 February 1910.

3"Sun' Newspaper , Boston, 25 March 1910.

4 lbid.

${ }^{5}$ HHSTA/PA. Austro-Hungarian consul . raport, Durrës 11 March 1910. Albanian language alphabet and Bitola Congress. Work cited, 394.

6HHSTA/PA Vienna's Archive, Durrës Vice-consul's information, 11 April 1909.

7 "Korça",Korçë nr. 34, 12 February 1910. Author: Krasta.

${ }^{8} \mathrm{Haxhi}$ Ali Elbasan was the deputy of Elbasan in the Turkish Parliament. He was the president of. Mahfeli society, which was organized in the beginning of 1910 in Istambul, which became the center of Arabic alphabet propaganda. According to Sejfi Vllamasit this club (society) was created in Aksaray in Istanbul.

9 "Bashkimi i Kombit",.Bitola nr.27 March 1910..Political and Social opinion of the Albanian Renaissance, article summary , Tiranë, 8 November 1976, 550.

10 "The History of Albanian People" work cited , 421.

11 "Sun" Newspaper, Boston, 25 March 1910.
} 
later, - says vice council of Durres - Important people of Elbasan and patriots gathered around thence clubs and organized a public rally with a large attendance which ended with the delivery of telegrams to Albanian Prime Minister and deputies "1. He estimates the participation in this rally about 2000 manifest.

Thus, the people of Elbasan, massively supported by the population of the province of Gramsh and other regions, will protect the writing of the Albanian language with the Latin alphabet. Among the organizers of the rally are mentioned the names of Lef Nosi, Beqir Plangarica, Muç Shqiptari Ali Ciftja , Ali Celirama, Nexhip Haxhiademi etc. As the leading role of the elders of the rally result Dervish Biçakçiu, Galip Bey, Mahmoud sheh Guma, Beqir Mezja, Emin Haxhiademi etc ${ }^{2}$. An event of such dimension is reflected in an article titled "patriotic rally in Elbasan" published in the newspaper "Sun", where among other things, assess the role and the contribution in this meeting of the important people of Elbasan claiming " ... joined the quickly also the hones important people of Elbasan, who almost was the soul and the heart of the national movement of these days "3. Even in the newspaper "Freedom" of Thessaloniki reflected the organized rally in Elbasan against the use of the Arabic alphabet for writing the Albanian language : "The script that comes from the government says: After this Albanian language will be taught with Arabic letters only to them who like to learn Albanian ... if they don't want, is better. "According to this information the rally for the protection of the alphabet with Latin letters was held on 4 February $1910^{4}$. Also, on the issue of Albanian alphabet, Jacques Edwin (Edwin E. Jacques) on his monograph "Albanians" wrote: "At that time no one could have imagined that in 1928 (so 18 years later - St. Our) Mustafa Kemal would require Turkey to write his own language with Latin letters thus following the example of its former vassal ". 5

It must be said that through the relevant documentation about the rally in question, different sources give different opinions in tors of the date of holding the rally in support of Latin letters and the number of participants in it. Some of these resources write that the date of the organization of the rally is 4 February 1910 , while other sources write the date February $5,1910^{6}$. Also in terms of the number of participants in this rally, there is the same problem that is reflected in data inconsistencies. Thus, in Durres's vice-consul information on the number of participants in this rally, is given a number nearly 2,000 participants, while newspapers "Shqiptari" gives a number about 10,000 people, ${ }^{7}$ while in other sources as well as the newspaper "Sun" of Boston was given a number of participants about 7,000 people. Also, the letter sent by the club "Bashkimi" and published in the newspaper "Tanin" in Istanbul on February 20, it was claimed that: "On February 5, all chiefs, sheikhs, merchants and guilds, as well as the population of the villages held a rally in which vowed to preserve the Albanian alphabet used for 40 years ... . ${ }^{8}$

But despite such a problem, it must be said that this rally to the extent that he had received and echoes inside and outside the country, can be considered as largest ever organized rally in Elbasan, which were made for the protection of the Latin alphabet on writing Albanian language. Regarding the echo that this rally had, in and out region of Elbasan and in the diaspora, on February 11th, 1910 the newspaper of Istanbul "Shqiptari", assessing the activity of Elbasan people would write: "The behaver of people of Elbasan honors us .... that holly place is the light of Albania and the heart of all its desires ". 9

Also, the Austro-Hungarian consul Pallavicinion his information sent to Vienna on February 1910, stated that: ". . The Young Turk's"Tannin"saw himself compelled to express the opinion that the right to use Latin letters to write the Albanian seems justifiable for language technical issues. If it formally presents the Young Turk Committee official's view, the article of the newspaper "Tanin" will temporarily resolve the conflict of the alphabet in favor of Latin letters ". ${ }^{10}$ Also, in the

\footnotetext{
${ }^{1}$ HHSTA/PA, Vienna's Archive, Durrës Vice-consul's information, 11 April 1909.

2 Elbasan- Encyclopedia, work cited, 117.

3 "Sun", Newspaper, Boston, 25 March 1910.

4 "Lirija", Thessaloniki, nr.75, February 1910. Author: B.R

5 Edwin E. Jacques, Albanians, II Edition, Abraham Lincoln Fondation, Tiranë, 1995, 449.

6 "Lirija" Newspaper in Thessaloniki as the date of its organization, gives 4 February 1910, while the newspaper. "Tanin" in Istanbul gives the date 5 February 1910.

${ }^{7}$ At 11 February 1910 the patriot Dervish Hima wrote on the newspaper of Istanbul "Shqiptari" : From Elbasan they inform us with a telegram that had been a rally to protect the Albanian letters. More than 10000 people participated and lots of words was said..."

${ }^{8} \mathrm{AME}$, Hasan Kaleshi, "Some aspects of the Albanian alphabet issue war in Istanbul".

9 The newspaper "Shqiptari" in Istanbul, 11 February 1910, Elbasan's Library.

${ }^{10}$ HHSTA/PA Pallavicini consul's rapport, Istambul February 1910. "Albanian language alphabet and the Congress of Bitola", work cited, 391.
} 
newspaper "Dielli" was estimated the participation in the rally of school Idadije students in Elbasan mentioning the names of the "fifth row " students, more specifically the names of Emin Haxhiademi, Kamber Dardha and Kostandin S. Cipos. ${ }^{1}$ It must be said that on the response that Gramsh patriots gave to turkman council on their request to support the Arabic letters was stated: "With great pleasure we submit that there is no people to attend as required, so we return this proposal". ${ }^{2}$ Also, in the press of the time were reflected the protests sent by Albanian representatives abroad, members of the Ottoman parliament against their attempts to impose the Arabic alphabet. Such a protest sent on behalf of Constance Albanian society is reflected in the newspaper "Albanian" published in Istanbul and in the newspaper "Bashkimi i Popullit" published in Bitola. ${ }^{3}$

The summer Young Turk expedition of 1910 not only didn't allow their implementation, but also arbitrarily closed the Normal school in September 1910, with the motive that its activity was "dangerous to religion and the constitution"4. Through such an action, only using force and violence Young Turks would temporarily inhibit the educational movement in Albania, while such a situation will serve as a catalyst accelerator towards the organization of the Albanian uprisings. In this context, in September of 1910 in Elbasan was declared a state of emergency and kept the city surrounded by the regiment. 7 The First Army Corps ${ }^{5}$. Sources inform us about the priest of Elbasan, who was moved to the Greth of Kavaja, was brought in Elbasan as wanted, but was acquitted versus a commercial guarantee. ${ }^{6} \mathrm{As}$ a result of such a situation, most of the Elbasan patriots and Normal school's teachers, to escape repression expedition of Turgut Pasha, fled abroad. Such were Luigi Gurakuqi, Alexander Xhuvani, Dervish Biçaku, Aqif Pashe Elbasani etc. Those who remained were physically abused or were deported to Anatolia. Lef Nosi, director of the "Tomori" newspaper was exiled to Bruce, while Simon Shuteriqi was physically mistreated. Moreover other patriots of Elbasan suffered the same fate. ${ }^{7}$

\section{Conclusions}

Passing from the end of the IX century to XX century, national movement in the region of Elbasan marks the transition from of a spontaneous character movement phase but with a specific purpose and objective, consistent with the Albanian national movement, toward an organizational character movement, which shaped and appear in spatial boundaries within and outside this country. The contribution of this region is present in almost all the important events of the Albanian National Movement that takes part on the period treated in this thesis often being put on top of them.

The movement for the alphabet, Albanian language and writing, would be considered already at the beginning of the XX century not only as a real language issue, but will take the size of a political nature movement, by interfering directly in solving common problems. This is because of the most known fact, that under Ottoman Empire repression, Albanians were denied from their language and Albanian schools. To Albanians was denied the Albanian language, because it was a clear expression of national identity and Albanian schools were denied because they are the institutions within which this identity would get full affirmation in the function of a significant political process.

Movement for the Albanian alphabet and writing in Albanian territories as the most important problem of the Renaissance, has its prehistory associated with solving the issues that along the XIX century would go beyond individual initiatives.

After the announcement of Hyrjetit (Turkish Constitution on July 23, 1908), in the framework of constitutional freedoms which would turn temporary, Albanian National Movement will be reorganized to show some features that consist of the following ways:

Firstly, from an illegal movement, after 1908 Albanian patriots would develop their activities in terms of constitutional freedoms undergoing a significant evolution in organizational terms

\footnotetext{
1 "Dielli", Boston, 25 March 1910.

2 "Lirija", Thessaloniki , 10 May 1910.

${ }^{3}$ Acts of Albanian Renaissance, work cited, 207- 208 .

4"Bashkimi i Kombit" Newspaper, nr. 26, Bitola, 4 March 1910, 2.

${ }^{5}$ HHST/PA nr.39, austro - hungarian consul's rapport, Durrës, 25 September 1910.

${ }^{6}$ lbid.

${ }^{7} \mathrm{AQSH}$, F.3, Doss. 45 p.9.
} 
Secondly, if before 1908 the Albanian patriots carrying out their activities in exile after 1908 their activity would be recorded significantly in the Albanian territories by creating patriotic clubs and societies. But it must be said that such a process would be found also in the center of the Ottoman Empire

Thirdly, through the intensification of the Albanian patriots activity would be created a dense network of organized Albanianism activities which included patriotic-cultural organizations that would significantly contribute to the strengthening of national identity among Albanians.

\section{BIBLIOGRAPHY}

[1] CENTRAL STATE ARCHIVE OF THE REPUBLIC OF ALBANIA, (A. Q. SH)

[2] Fund. " Patriotic clubs and societies ", nr. 102

[3] Fund. 3, Dossier 45

[4] ETHNOGRAPHIC MUSEUM ARCHIVE OF ELBASAN (AME)

[5] HISTORY INSTITUTE ARCHIVE, Tiranë. Fund of the Ministry of Foreign Affairs of Vienna, HH ST PA:

[6] Elbasan-Encyclopedia, Elbasan, Sejko, 2004

[7] Clayer, N. At the beginning of Albanian nationalism, birth of a majority Muslim nation in Europe, Tiranë, "Përpjekja", 2009

[8] Political and Social opinon of the Albanian Renaissance 1908 - 1910, Zihini Haskaj, II Edition, Tiranë 1976

[9] "Bashkimi i Kombit", Bitola, nr. 27 March 1910

[10] "The Sun" Newspaper, 1 October 1909

[11] "Freedom" Newspaper, Thessaloniki, nr. 75, February 1910

[12] "Korça" Newspaper, Korçë 1909 